\title{
THE SOUNDING OF GLACIERS
}

TECHNIQUE DES SONDAGES SOUS-GLACIAIRES. A. BouRgin. Revue de Géographie Alpine (Grenoble). Tome 38, Fasc. 4, I950, p. 623-32.

LES SONDAGES SISMIQUES DE LA COMMISSION HELVÉTIQUE DES GLACIERS. A. Renaud and P. L. Mercanton. Publications du Bureau Central Sèismologique International, Série A, Travaux Scientifiques, Fasc. 77 , 1950, p. 66-78. (Mémoires présentés à l'Assemblée d'Oslo I948.)

DETAILED information on subglacial conditions is clearly a fundamental necessity for the advance of scientific glaciology. It is most desirable, therefore, to publish as many details as possible of available techniques of glacier sounding, and the relative success of these. There has been very considerable activity in this field in connexion with recent hydrological surveys in Europe, particularly in France and Switzerland, and reports on glacier soundings from these countries are, therefore, especially welcome. Both of the above papers include discussions of the theoretical backgrounds and development of the techniques used, together with some details of recent work. In the case of the Swiss glaciers the seismic method was employed, on the French glaciers thermal borings were also used.

It is clear that most valuable results have been obtained. Of those already published the detailed cross-section of the Mer de Glace, showing a V-shaped profile very different from that which would be expected according to orthodox views, will perhaps be of particular interest to glaciologists. We must be grateful that in many instances the glaciers investigated by the hydrological commissions have been the same as those of which many other studies have already been made. The new results are of so much the greater value to us.

It would appear that the writers of the papers are, on the whole, conversant only with Continental sources, and although Renaud and Mercanton mention the work of Perutz in 1948 on thermal soundings, Bourgin is clearly unaware that the method was developed quite independently by Perutz and Gerrard. However, such lack of contact must of necessity disappear with the publication of papers such as these.

Department of Geography, Cambridge

JEAN M. Clark

SNOW AND ICE PROBLEMS IN CANADA AND THE U.S.A. Marcel R. DE QueRVAIN. National Research Council of Canada, Division of Building Research; Technical Report No. 5. February, 1950, 69 pages, illustrations, diagrams, 3 appendixes.

IN 1948, by arrangement with the Swiss authorities, Dr. M. R. de Quervain went to North America as a guest member of the staff of the National Research Council of Canada, Division of Building Research. The main purpose of the visit was to examine the problems of snow and ice in relation to the Canadian economy. The report on his findings, submitted by Dr. de Quervain and published by the National Research Council, is a notable contribution to the advancement of snow and ice study in Canada and the U.S.A.

In a preface, Mr. R. F. Legget, Director of the Building Research Division, states that "possibly the most important result of Dr. de Quervain's visit was the demonstration that the basic problems of the two countries (Switzerland and Canada) are fundamentally identical." The difference, emphasized by the report, is the varying importance attached to those problems. Dr. de Quervain points out that "in Switzerland, avalanches are problem number one whereas ice jams on rivers are quite subordinate." In Canada the reverse is the case.

To quote from the report, glaciers are "the least important from the practical standpoint. Their hydrological influence is rather local with regard to the vast dimensions of the country." The rate 